\section{Carryover Effects of Prohexadione-calcium on Apples}

\author{
Duane W. Greene \\ Department of Plant, Soil, and Insect Sciences, University of Massachusetts, \\ Amherst, MA 01003
}

Additional index words. Apogee, Regalis, growth retardant, BAS 125, growth control, apple scab, fire blight, pest control

\begin{abstract}
Proheaxadione-calcium (ProCa) was applied to 'Spencer' apple trees at rates between 250 to $750 \mathrm{mg} \cdot \mathrm{L}^{-1}$ after harvest but before leaf fall. The following spring terminal growth was reduced linearly from early petal fall through the growing season to leaf fall. ProCa was applied after harvest and before leaf fall at $500 \mathrm{mg} \cdot \mathrm{L}^{-1}$ to 'Spigold' apples. The carryover effect on terminal growth persisted for about 2 weeks after bloom. A combination of 500 and $82.5 \mathrm{mg} \cdot \mathrm{L}^{-1}$ ProCa on 'Spigold' in the fall and spring, respectively, reduced terminal growth greater than the individual treatments for about 3 weeks after petal fall. Recent report have shown that ProCa can induce physiological resistance to fire blight and apple scab when applied near petal fall. These data support the suggestion that ProCa may be used as a fall application and the carryover effects may result in early growth control. Potential benefits of the carry-over effects of ProCa for early-season suppression of fire blight and apple scab are discussed.
\end{abstract}

Prohexadione-calcium (ProCa) is a new plant growth regulator that was initially registered to control terminal growth on apples. Peripheral effects on apples as a direct result of growth retardation included better spray coverage of other sprays, reduced amounts of spray need to cover foliage, improved fruit color, and a reduced time required to prune (Miller, 2002). More recently ProCa has been shown to reduce fire blight, scab, aphids and leafhoppers on apples. These later responses are not due to direct inhibition by ProCa but as a result of result induced physiological resistance, caused by a build up of phenolic compounds which are not formed under normal conditions (Roemmelt et al., 2003).

The first application ProCa is made commercially when terminal shoot growth is 2 to $5 \mathrm{~cm}$. This timing is selected since a minimum leaf surface is required for good uptake of the active ingredient and this is the earliest that sufficient leaf area has unfolded to achieve adequate uptake (Rademacher and Kober, 2003). It requires between 10 to $14 \mathrm{~d}$ after application for ProCa for growth retardation to occur and effects to become evident (Greene, 1999). Due to the very rapid shoot growth starting at bloom it is possible, particularly in cool growing areas, to have $>50 \%$ of the total terminal growth of an apple tree occur in the spring before the full growth retarding effects of ProCa can be established (Unrath, 1999).

Similarly, it appears to take between 7 and $20 \mathrm{~d}$ following ProCa application for metabolic changes to take place that result in development of resistance to diseases and insects (Bazzi et al., 2003). Before the time of ProCa application and during the period that trees are developing resistance to fire blight and scab there is serious disease pressure that must be controlled with pesticides or antibiotics. Clearly, there are potential benefits to having ProCa in the shoots

Received for publication 8 Sept. 2004. Accepted for publication 9 Feb. 2005. at the time buds start to break to initiate early growth control and also present when tissues become susceptible to diseases.

It is generally accepted that ProCa is degraded relatively rapidly within the plant (Rademacher and Kober, 2003). Consequently more than one application is required to achieve adequate and season long growth control. It is estimated that ProCa has a half life of a few weeks (Evans et al.,1999). For this reason carryover effects of ProCa from applications made according to label suggestions have been neither observed nor reported. Metabolism slows as temperature goes down, thus slowing the degradation of any applied growth regulator, including ProCa. There are many reports in the literature of carryover effects of applied growth regulators including aminoethoxyvinylglycine (Greene, 1983; Williams, 1981), daminozide (Forshey, 1970; Lord, 1971), ethephon (Williams, 1975), and paclobutrazol (Elfving and Proctor, 1985; Lever, 1986). Generally, the later in the season and the higher the concentration, the greater the carryover effect (Greene et al., 1986; Southwick et al., 1973).

In some apple growing areas, such as the northern tier of states in the United States, there occurs a relatively rapid transition to cold weather after harvest in the fall. One can hypothesize that metabolism of ProCa under these conditions may be slowed sufficiently, such that significant and physiologically active levels of this compound may persist in the tree over the winter and elicit a response early the following year. This investigation was initiated to determine if carryover effects of ProCa could be documented from a late fall postharvest application on apples.

\section{Materials and Methods}

Plant material. Trees used in this experiment were propagated on M.7 rootstock growing at the University of Massachusetts Horticultural Research Center in Belchertown,
Mass. Pruning, training, maintenance, and pest control were done according to normal commercial practices.

Experiment 1: 'Spencer'1999-2000. Following harvest a block containing 24 Spencer apples trees were selected and blocked into 6 groups (replications) of 4 trees each based upon proximity in the row and tree vigor. On 29 Oct., one tree in each block was sprayed with a commercial airblast sprayer at tree row volume dilute with 250,500 , or $750 \mathrm{mg} \cdot \mathrm{L}^{-1}$ ProCAcontaining $0.05 \%$ Silwet L- 77 , a proprietary silicone polyether copolymer (Loveland Industries, Loveland, Colo.). Temperature at the time of application was $20^{\circ} \mathrm{C}$. The remaining tree in each block was left unsprayed and served as the untreated control. Foliage was exposed to light frosts and was showing signs of senescence as evidenced by yellowing of some leaves. At the pink stage of flower development the following spring two limbs per tree 10 to $15 \mathrm{~cm}$ in diameter were tagged and all flower clusters counted. Starting a full bloom and periodically through the growing season, terminal growth was taken on 20 randomly selected shoots per tree. At the end of June drop in July, all flower clusters were counted on the tagged limbs. At the normal commercial harvest time a 20 apple sample was randomly harvested from the periphery of the tree. These fruit were weighed and the surface red color of each was then visually estimated to the nearest $10 \%$. Fruit were placed in a V-shaped trough where the cumulative length and diameter were measured, and from this the fruit length to diameter ratio ( $\mathrm{L} / \mathrm{D}$ ratio) was calculated. A subsample of 10 fruit, representative of the sample, was selected and flesh firmness determined on two sides of each fruit using an Effegi model FT 327 penetrometer equipt with an 11.1-mm head (McCormick Fruit Co., Yakima, Wash.). Fruit soluble solids were determined on a composite sample of juice collected while doing the flesh firmness, using a hand-held refractometer (Fisher, Pittsburgh, $\mathrm{Pa}$.). Fruit for the firmness test were cut in half, dipped in a starch-iodine solution, and the starch pattern then rated using a generic starch chart (Blanpied and Silsby, 1992).

Experiment 2: 'Spigold' 2001-02. Following harvest 28 'Spigold' trees were selected based on proximity in the row and terminal growth, and grouped into 7 groups (replications) of 4 trees each. Two trees in each block were sprayed with a commercial airblast sprayer at TRV dilute with $500 \mathrm{mg} \cdot \mathrm{L}^{-1}$ of ProCa containing $0.05 \%$ Silwet L- 77 on 3 Nov. Temperature at the time of application was $13{ }^{\circ} \mathrm{C}$. Leaves showed some damage due to previous frosts. The following spring at petal fall, 5 May 2002, one tree in each block that received ProCa the previous fall and one tree that was untreated the previous fall were sprayed with a commercial airblast sprayed at TRV dilute with $82.5 \mathrm{mg} \cdot \mathrm{L}^{-1}$ ProCa containing $0.05 \%$ Regulaid surfactant (Kalo Agricultural chemicals, Overland park, Kans.), and 1892 $\mathrm{mL} / 379$ L Quest water conditioner (a proprietary water conditioner blend of ammonium salts of polyacrylic, hydroxycarboxylic and phosphoric acids, Helena, Chemical Co., Col- 
lierville, Tenn.). One of the four trees in each group did not receive ProCa either in the fall or spring and served as the untreated control. Terminal growth was taken on 20 randomly selected shoots just before application on May 11 and then weekly through 29 June. Final Shoot growth was taken on dormant shoots on 6 Dec. A 20-apple sample was randomly harvested from the periphery of each tree at the normal harvest time and weight and fruit L/D ratio taken as previously described.

Statistical analysis. Both experiments were set up as a randomized complete block design. Analysis of variance was used to determine significance of treatments. Where appropriate, means were separated by orthogonal polynomial comparison or by Duncan's new multiple range test.

\section{Results}

Experiment 1: 'Spencer'. Terminal growth of shoots at full bloom were significantly shorter on trees treated the previous fall with ProCa (Table 1) The response was linear and highly significant and persisted for over 4 weeks. A significant linear carryover effect still existed when final terminal growth was taken in the dormant period on $1 \mathrm{Dec}$. The carryover effect of ProCa had no influence on final fruit set and fruit weight, flesh firmness, soluble solids, L/D ratio, or starch rating of fruit at harvest (data not shown).

Experiment 2: 'Spigold'. Terminal growth of shoots treated with ProCa during the previous fall were less then those not treated (Table 2) The reduction in terminal growth as a result of the carryover effect persisted for only between 2 to 3 weeks. Reduction in terminal growth as a result of the petal fall application was measured 2 weeks after application. The greatest reduction in terminal growth occurred 2 and 3 weeks after petal fall on trees receiving both a fall and a petal fall application of ProCa. When final shoot growth was taken in the dormant season a significant reduction in shoot growth occurred only on trees that received both a fall and spring application of ProCa. No treatment influenced fruit weight or $\mathrm{L} / \mathrm{D}$ ratio of fruit at harvest (data not shown).

Table 1. Effect of Prohexadione-calcium (ProCa) applied after harvest on 23 Oct., 1999 on terminal growth of 'Spencer' apples in 2000.

\begin{tabular}{lcccccc}
\hline $\begin{array}{l}\text { Treatment } \\
\left(\mathrm{mg} \cdot \mathrm{L}^{-1}\right)\end{array}$ & \multicolumn{7}{c}{ Terminal growth $(\mathrm{cm})$} \\
\cline { 2 - 7 } & 15 May & 22 May & 30 May & 5 June & 19 June & 1 Dec. \\
\hline ProCa 0 & 4.1 & 6.8 & 12.1 & 16.9 & 23.5 & 29.2 \\
ProCa 250 & 3.7 & 6.7 & 11.1 & 14.3 & 21.3 & 25.4 \\
ProCa 500 & 3.4 & 5.7 & 10.3 & 15.0 & 20.9 & 26.0 \\
ProCa 750 & 3.1 & 5.2 & 9.1 & 11.7 & 16.9 & 19.2 \\
Significance & $\mathrm{L}^{* * *}$ & $\mathrm{~L}^{* * *}$ & $\mathrm{~L}^{* * *}$ & $\mathrm{~L}^{* * *}$ & $\mathrm{~L}^{* * *}$ & $\mathrm{~L}^{* * *}$ \\
\hline
\end{tabular}

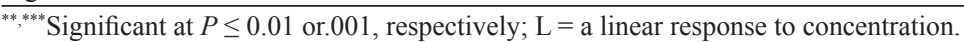

Results from this experiment confirm that sufficient ProCa can remain in the tree from a late fall foliar application to retard early shoot growth the following spring. The magnitude of the reduction will depend upon several factors including concentration of ProCa applied, the time of application, the conditions of the foliage at the time of applications and the temperature following application. These experiments confirm that there was a linear reduction of terminal growth with increasing concentration, thus the higher the rate the greater the carryover effect. The ideal time of application would be late, to enhance the chances of a significant amount of residue remaining in the tree. However, the time of application is largely determined by temperature, particularly frost or freezes and how they influence leaf quality and leaf abscission. Thus, the time of application may vary from year to year, and determined largely upon temperature effects on leaf quality. Little is known about the effects of frosts and the onset of senescence on foliar penetration and translocation to buds. This would be an appropriate area for future studies. Once translocated to growing points, the amount of ProCa remaining in the tree will depend upon degradation, which is undoubtedly influenced and largely determined by temperature. Therefore, cooler temperature and regions that routinely experience cool to cold temperature after harvest will be the areas where the benefits of a ProCa are most likely to be realized. Specific temperature ranges that favor or allow ProCa accumulation must still be worked out.

Fire blight generally enters the tree either through blossoms or vegetative tissue. Blossom blight infection is most severe during the bloom period whereas shoot blight generally enters the tree on rapidly growing shoots. ProCa is less effective on controlling blossom blight primarily because application is made after the peak period of susceptibility, and once present in the tissue, it requires from one to three weeks for resistance to develop. It would be an important breakthrough in blossom blight control if sufficient ProCa could be present in the tissue at bloom, the primary of inoculation.

\section{Discussion}

Table 2. Effect of Prohexadione-calcium (ProCa) applied after harvest on 3 Nov. 2000 on terminal growth of 'Spigold' apples in 2001.

\begin{tabular}{|c|c|c|c|c|c|c|c|c|c|}
\hline \multirow[b]{2}{*}{ Treatment } & \multicolumn{9}{|c|}{ Terminal growth $(\mathrm{cm})$} \\
\hline & $5-11$ & $5-18$ & $5-25$ & $5-31$ & $6-8$ & $6-15$ & $6-22$ & $6-29$ & $12-6$ \\
\hline Control & $6.9 \mathrm{a}^{\mathrm{z}}$ & $8.5 \mathrm{a}$ & $12.4 \mathrm{a}$ & $15.5 \mathrm{a}$ & $22.4 \mathrm{a}$ & $30.2 \mathrm{a}$ & $33.3 \mathrm{a}$ & $33.5 \mathrm{a}$ & $43.8 \mathrm{ab}$ \\
\hline ProCa $500 \mathrm{mg} \cdot \mathrm{L}^{-1} 11-3-00$ (fall) & $5.0 \mathrm{~b}$ & $7.1 \mathrm{~b}$ & $10.3 \mathrm{~b}$ & $13.8 \mathrm{a}$ & $20.9 \mathrm{a}$ & $27.5 \mathrm{~b}$ & $31.4 \mathrm{a}$ & $35.9 \mathrm{a}$ & $47.7 \mathrm{a}$ \\
\hline ProCa $82.5 \mathrm{mg} \cdot \mathrm{L}^{-1} 5-11-01+$ Quest (spring) & $6.7 \mathrm{a}$ & $8.6 \mathrm{a}$ & $10.4 \mathrm{~b}$ & $11.8 \mathrm{~b}$ & $13.3 \mathrm{~b}$ & $15.1 \mathrm{c}$ & $15.0 \mathrm{~b}$ & $14.7 \mathrm{~b}$ & $33.8 \mathrm{bc}$ \\
\hline ProCa fall and spring & $4.7 \mathrm{~b}$ & $6.4 \mathrm{~b}$ & $8.6 \mathrm{c}$ & $9.9 \mathrm{c}$ & $11.7 \mathrm{~b}$ & $13.1 \mathrm{c}$ & $12.6 \mathrm{~b}$ & $13.0 \mathrm{~b}$ & $26.9 \mathrm{c}$ \\
\hline
\end{tabular}

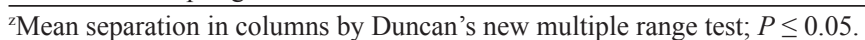

The main control of blossom blight is with antibiotics and the possibility exists that resistance can be built up with overuse. A second tool to control this disease may either defer or prevent development of resistance. Pro-Ca has the potential to control blossom blight (Buban etal., 2003) but weather conditions and tree phenological development are generally unfavorable for adequate uptake at this time of year (Rademacher, 2004). Establishing effectiveness from a carryover effect appears to be the next logical step in determining efficacy of ProCa on blossom blight.

Apple scab is a ubiquitous fungi that is a major problem in all humid apple growing regions. Apple tissue is susceptible to infection as soon as green tissue emerges in the spring and environmental conditions for spore release are present. Spores are released and infections occur multiple times when thresholds of temperature and wetting times are reached. The majority of these infections generally occur before bloom, thus before ProCa is applied and can become effective. Strategies to control scab include the use of more than one fungicide to reduce the risk of developing resistance to useful materials. If sufficient quantities of ProCa could be present in the tissue at shoot break, it may provide another source of control and extend the useful life of existing fungicides. There are additional and distinct advantage to having a resistance to scab present in the tree early. In some years it may to too wet to drive a sprayer though an orchard at critical times or prolonged periods of rain may prevent timely application of fungicides. While materials are available for post-infection control, undoubtedly the easiest and most useful method of control would be to have a material with fungicidal activity in place to control infections under these very difficult application situations.

Because of the very rapid shoot growth following bloom, especially in the cooler growing areas (Unrath, 1999), there is a distinct advantage to having initiation of growth control earlier than can be achieved by a petal fall application of ProCa. In the experiment using 'Spigold', greater shoot growth control was achieved from a combined fall and spring application than from from a single spring application in the spring, but the difference persisted for only 3 weeks. It is now established that the addition of a water conditioner, regardless of water $\mathrm{pH}$ or hardness, will enhance the effectiveness of ProCa (Byers et al., 2004; Schupp et al., 2003). A water conditioner was used in the spring application but not in the previous fall. If a water conditioner had been used in the fall applications the chances are great that the carryover effect would have been even greater than reported here.

HORTSCIENCE VOL. 40(5) AUGUT 2005 
The rate of ProCa used in this investigation to achieve carryover effects may have approached or exceeded legal limits dictated by the label. The current recommendations are based on the assumption that fruit will be harvested from the trees the same year that they are sprayed. However, in this investigation application is made after harvest leaving nearly a year between application and harvest. Label revision to allow higher rates of application seems to be in order. Further, increased rates may translate into reduced use of some pesticides and lengthening the time that some pesticides may be used.

\section{Literature Cited}

Bazzi, C. Messina, L. Tortorto, E. Stefani, F. Bini, A. Brunelli, C. Andreotti, E. Sabatini, F. Spinelli, G costa, S Hauptmann, G. Stammler, S. Doerr, J. Marr, and W. Rademacher. 2003. Control of pathogen incidence in pome fruit and other horticultural crop plants with prohexadione-Ca. Euro. J. Hort. Sci. 68:108-1114.

Blanpied, G.D. and K.J. Silsby. 1992. Predicting harvest date windows for apples. Cornell Coop. Ext. Info. Bul. 221.

Buban, T., L. Foeldes, A. Kormany, S. Hauptmann, G. Stammler, and W. Rademacher. 2003. Prohexadione-Ca in apple trees: control of shoot growth and reduction of fire blight incidence in blossoms and shoots. J. Appl. Bot. 77:95-102.

Byers, R.E., D.H. Carbaugh, and L.D. Combs. 2004.
Prohexadione-calcium suppression of apple tree shoot growth as affected by spray additives. HortScience 39:115-119.

Elfving, D.C. and J.T.A. Proctor. 1986. Long-term effects of paclobutrazol (Cultar) on apple-tree shoot growth, cropping, and fruit-leaf relations. Acta Hort. 179:473-480.

Evans, J.R., R.R. Evans, C.L. Regusci, and W. Rademacher. 1999. Mode of action, metabolism, and uptake of BAS $125 \mathrm{~W}$, prohexadione-calcium. HortScience 34:1200-1201.

Forshey, C.G. 1970. The use of Alar on vigorous 'McIntosh' apple trees. J. Amer. Soc. Hort. Sci. 95:64-67.

Greene, D.W. 1983. Effect of chemical thinners on fruit set and fruit characteristics of AVG-treated apples. J. Amer. Soc. Hort. Sci. 108:415-419.

Greene, D.W. 1999. Tree growth management and fruit quality of apple trees treated with prohexadione-calcium (BAS 125). HortScience 43:1209-1212.

Greene, D.W., W.J. Lord, F.W. Southwick, and J.E. Sincuk. 1986. Effects of postharvest and postbloom sprays of daminozide on apples. Fruit Var. J. 40:41-45.

Lever, B.G. 1986. 'Cultar'-A technical overview. Acta Hort. 179:459-466.

Lord, W.J. 1971. Effect of annual sprays of succinic acid 2,2-dimethyhydrazide on vegetative growth, fruiting, fruit quality, and preharvest drop of 'Delicious' apple trees. J. Amer. Soc. Hort. Sci. 96:687-690.

Miller, S.S. 2002. Prohexadione-calcium controls vegetative shoot growth in apple J. Tree Fruit Prod. 3:11-28.
Rademacher, W. and R. Kober. 2003. Efficient use of prohexadione-Ca in pome fruit. Euro. J. Hort. Sci. 68:101-107.

Rademacher, W. 2004. Prohexadione-Ca induces resistance to fireblight and other diseases. OEPP/EPPO Bul. 34:383-388.

Roemmelt, S., T.C. Fischer, H. Halbwirth, S. Peterk, K. Schlangen, J.B. Speakman, D. Treutter, G. Forkmann, and K. Stich. 2003. Effect of dioxygenase inhibitors on the resistance-related flavonoid metabolism of apple and pears: Chemical, biological and molecular aspects. Euro. J. Hort. Sci. 68:129-136.

Schupp, J.R., T.L. Robinson, W.P. Cowgill, Jr., and J.M. Compton. 2003. Effect of water conditioners and surfactants on vegetative growth control and fruit cracking of 'Empire' apple caused by prohexadione-calcium. HortScience 38:1205-1209.

Southwick, F.W., W.J. Lord, D.W. Greene, and L.G. Cromack. 1973. Residual effects of summer applications of succinic acid, 2,2-dimethylhydrazide on 'McIntosh' apple trees. J. Amer Soc Hort. Sci. 98:593-595.

Unrath, C.R. 1999. Prohexadione-Ca: A promising chemical for controlling vegetative growth of apples. HortScience 34:1197-1200.

Williams, M.W. 1975. Carry over effect of ethephon on fruit shape of 'Delicious' apples. HortScience 10:523-524.

Williams, M.W. 1981. Response of apple trees to aminoethoxyvinylglycine (AVG) with emphasis on apical dominance, fruit set, and mechanism of action of fruit thinning chemicals. Acta Hort. 120:137-141. 